\title{
Perancangan Sistem Informasi untuk Solusi Permasalahan Transparansi Uang Amal Masjid di Suatu Wilayah dengan Metode Rapid Application Development (RAD)
}

\author{
Rizkyah Erwanda 120117067
}

Telkom University

Email: kiaerwnd@telkomuniversity.ac.id

\begin{abstract}
. Pada dewasa ini, beberapa orang mungkin terlintas dalam pemikirannya terkait uang amal masjid yang seringkali kita sedekahkan. Sepengetahuan kita, uang tersebut tentunya dipergunakan untuk merawat serta kebutuhan masjid itu sendiri. Namun ketika dipikir ulang, transparansi terkait uang amal masjid masihlah sangat minim. Masyarakat masih menggunakan cara konvensional dimana jumlah uang amal akan disebutkan nominalnya ketika sedang melakukan shalat jum'at. Berawal dari hal tersebut, penulis mulai memikirkan permasalahan-permasalahan lainnya yang turut muncul seperti ketimpangan yang terjadi akibat orang-orang pada umumnya memilih untuk melakukan ibadah di masjid yang bagus dan beramal disana sehingga masjidmasjid yang sebenarnya masih perlu dikembangkan menjadi semakin tertinggal.
\end{abstract}

Keywords: Sistem Informasi, Aplikasi, Uang Amal, Donasi, Transparansi, Masjid, RAD

Paper ini akan dipublikasikan di osf.io [a] menggunakan format standard perancangan sistem informasi [b]

\section{Introduction}

\subsection{Business case}

1.1.1. Project Definition

Sistem Informasi yang diusulkan berupa sistem informasi terkait transparansi uang amal dari setiap masjid di suatu wilayah. Alasan megembangkan sistem informasi ini ialah karena selama ini masyarakat selalu memikirkan bahwa uang amal yang seringkali mereka amalkan ialah untuk kebutuhan masjid seperti mencuci karpet, membeli alat kebersihan, dan sebagainya. Namun sebenarnya jumlah dan aliran uang tersebut masih menjadi pertanyaan. Karena selama ini, informasi terkait uang amal masih hanya diinformasikan secara konvensional, yaitu disela-sela pertengahan shalat jum'at. Selain hal tersebut, alasan lainnya ialah terkait ketimpangan yang terjadi akibat orangorang memilih untuk melakukan ibadah di masjid yang bagus dan beramal disana sehingga masjidmasjid yang masih perlu dikembangkan menjadi semakin tertinggal.

\subsubsection{Project Objective}

Terdapat dua tujuan dari dirancangnya sistem informasi ini, yaitu:

1. Timbul 'kepercayaan' sebagai reaksi dari aksi yang dilakukan. Dengan membangun kepercayaan dan transaransi seperti 'mengetahui ternyata uangnya disumbangkan untuk yatim piatu' dan semacamnya, diharapkan mampu menggerakkan hati manusia untuk semakin banyak melakukan amal.

2. Orang-orang dapat mengetahui masjid mana yang sekiranya memerlukan dana namun sulit didapatkan karena jama'ah yang relatif sedikit karena wilayah kurang strategis maupun pendapatan masyarakat sekitar yang rendah, sehingga orang lain atau donatur lain dapat melakukan amal baik dengan cara online melalui website maupun mendatangi masjid itu secara langsung karena alamat setiap masjid dan nama pengurus telah dicantumkan. 


\subsection{System Requirement}

\subsubsection{System Function}

Sistem menurut Jogianto (2005:2) adalah kumpulan dari elemen-elemen yang berinteraksi untuk mencapai suatu tujuan tertentu. Sistem ini menggambarkan suatu kejadian-kejadian dan kesatuan yang nyata seperti tempat, benda, dan orang-orang yang betul-betul ada dan terjadi. Pada projek ini, sistem yang akan dirancang yaitu meliputi penyebaran informasi terkait transparansi uang amal beserta aliran keluar-masuknya kepada para donatur, proses amal online hingga pemantauan website oleh pengelola aplikasi.

Selain itu, terdapat juga beberapa fungsi didalam aplikasi ini, diantaranya:

1. Mempermudah pengurus masjid untuk melakukan transparansi uang amal kepada para jama'ah atau donatur. Fungsi ini membuat pengurus masjid menjadi lebih leluasa dan mendetail terkait aliran dana keluar-masuk dari uang amal yang dikelola selama mengurus masjid seperti pengeluaran perbulannya dan untuk apa.

2. Mempermudah penyampaian informasi kepada para donatur yang ingin beramal ke masjid yang kekurangan dana untuk pembangunan, dimana hal tersebut juga berguna untuk memajukan pembangunan masjid secara merata.

3. Selain informasi, para donatur atau jama'ah juga dapat melakukan amal online melalui transfer.

\subsubsection{System Feature}

Selanjutnya terkait fitur sistem, sistem ini mampu menampilkan masjid-masjid yang berada di suatu wilayah serta laporan keuangan dari amal masjid tersebut. Sistem ini juga mampu untuk melakukan amal online dimana pengguna bisa langsung melakukannya kepada masjid yang dipilih melalui aplikasi website.

\subsubsection{Acceptance Criteria}

Untuk Acceptance Criteria dari sistem ini ialah informasi terkait nominal aliran uang amal baik keluar maupun masuk harus dapat diakses oleh siapa saja dan dimana saja, serta up to date sebagaimana mestinya.

\subsubsection{System User Level}

User yang dapat mengakses sistem ini, diantaranya:

a. Donatur

Jama'ah atau orang lain yang ingin menyumbangkan hartanya dan dipercayakan ke suatu masjid

b. Pengelola Sistem

Orang yang merancangan dan mengembangkan serta memantau aktivitas yang ada pada sistem

c. Admin Masjid

Orang atau perwakilan dari pihak masjid yang mengurus masjid dan mengelola keuangan uang amal yang ada pada masjid tersebut, serta telah di validasi oleh pihak pengelola sistem

Click or tap here to enter text.

\section{Penjelasan SIngkat Terkait Metode}

Pada rancangan sistem ini, penulis menggunakan metode RAD (Rapid Application Development), berikut gambar visualisasi tahapan metode RAD: 


\section{Rapid Application Development (RAD)}

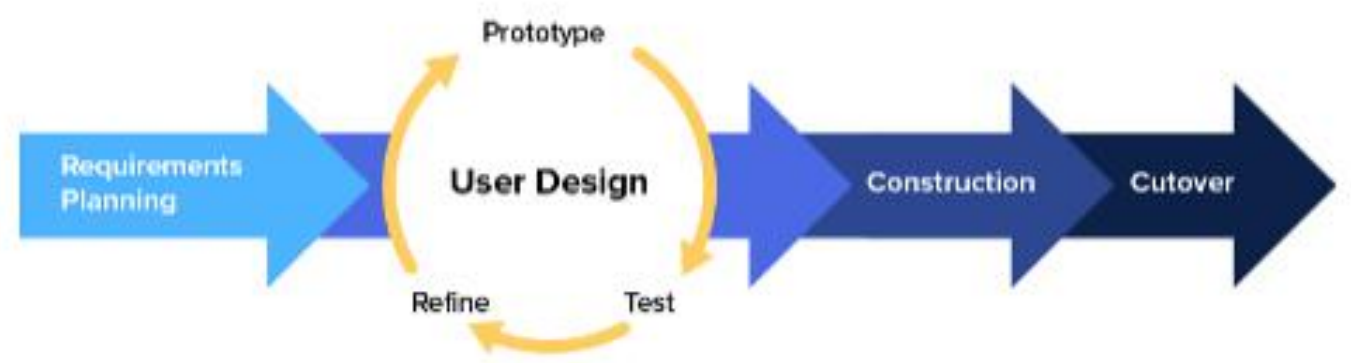

Figure 1 Metode RAD

Sumber: https://badoystudio.com/metode-pengembangan-perangkat-lunak/metode-rad/

Menurut McLead (2002), Rapid Application Development (RAD) adalah strategi siklus hidup yang ditujukan untuk menyediakan pengembangan yang jauh lebih ceat dan mendapatkan hasil dengan kualitas yang lebih baik dibandingkan dengan hasil yang dicapai melalui siklus tradisional. Sedangkan menurut Bentley (2004) RAD merupakan gabungan dari bermacam-macam teknik terstruktur dengan teknik prototyping dan teknik pengemangan joint application untuk mempercepat pengembangan sistem atau aplikasi. Dari kedua pernyataan diatas, dapat diketahui bahwa metode RAD ini sangatlah cocok untuk pengembangan sistem informasi dengan waktu pengembangan yang cukup singkat, dimana kunci dari RAD tersebut dapat dilihat pada Figure 1.

Selain itu, menurut Kendall (2010), terdapat tiga fase dalam RAD yang melibatkan pengalisis dan pengguna dalam tahap penilaian, perancangan, dan penerapan. Adapun ketiga fase tersebut adalah:

1. Requirements Planning: Fokus terhadap upaya pencapaian tujuan-tujuan perusahaan

2. RAD Design Workshop: Pengguna merespon prototipe yang ada dan penganalisis memperbaiki modul-modul yang dirancang berdasarkan respon pengguna.

3. Implementation: Pengalisis bekerja dengan para pengguna secara intens selama wokrshop dan merancang aspek-aspek bisnis dan nonteknis perusahaan.

\section{Proses Perhitungan}

3.1.System Design

3.1.1 Analisis Stakeholder

- Owner : Pengelola Aplikasi

- User : Customer (Donatur), Admin Masjid, Pengelola Aplikasi

- Customer : Donatur (Jama'ah)

- Analyst : :Tim Analisis

3.1.2 Analisis User Role

- Customer : Melihat aliran uang amal maupun memilih masjid yang ingin di sedekahkan

- Admin Masjid : Melaporkan aliran uang amal baik aliran masuk maupun keluar

- Pengelola : Memantau aktivitas-aktivitas yang berjalan di Aplikasi

3.1.3 Proses Bisnis Eksisting

Penulis belum menemukan adanya aplikasi sejenis terkait transparansi uang amal selama membuat rancangan sistem informasi ini. 


\subsubsection{Proses Bisnis Usulan}

Penulis mengusulkan untuk membuat aplikasi terkait transparansi uang amal, yang selama ini masih dilakukan secara konvensional saat disela-sela shalat jum'at saja.

\subsection{Data Flow Diagram (DFD)}

Menurut Jogiyanto (2005), Data Flow Diagram (DFD) adalah diagram yang menggunakan notasi simbol untuk menggambarkan arus data system.

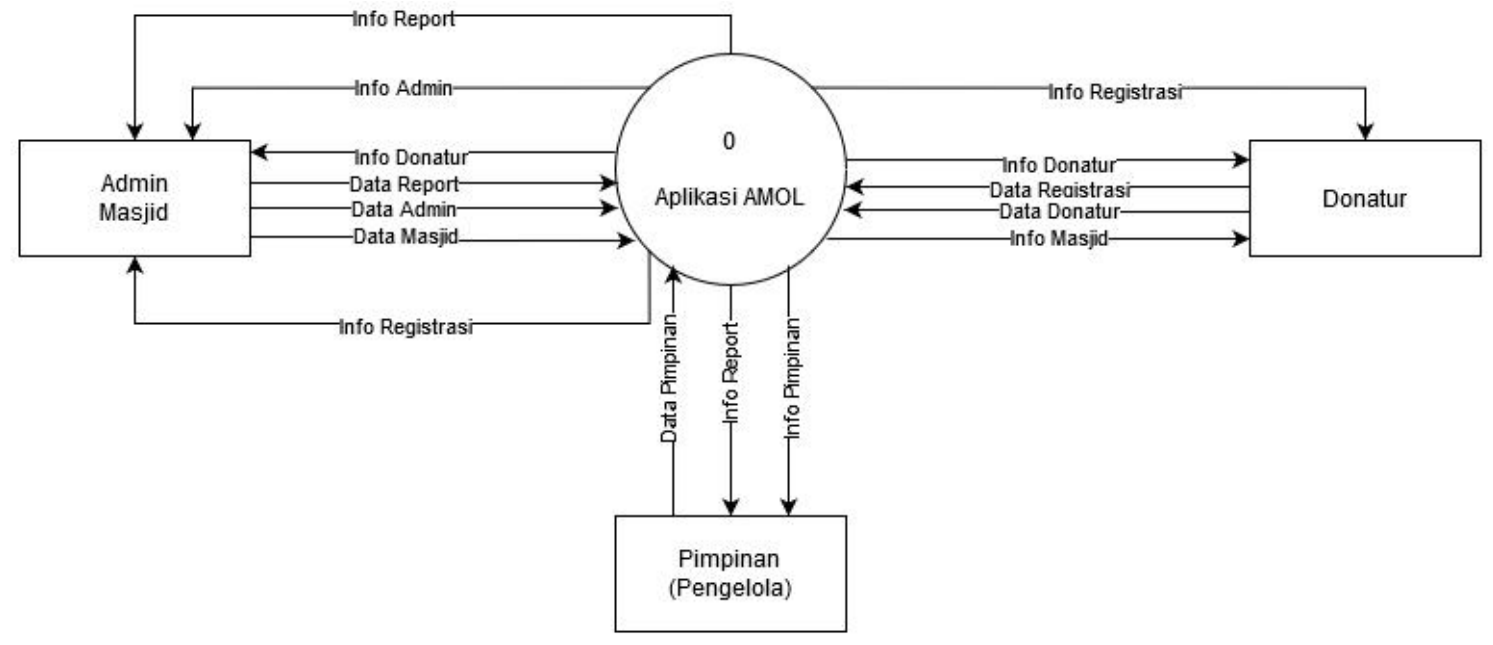

Figure 2 DFD Level 0

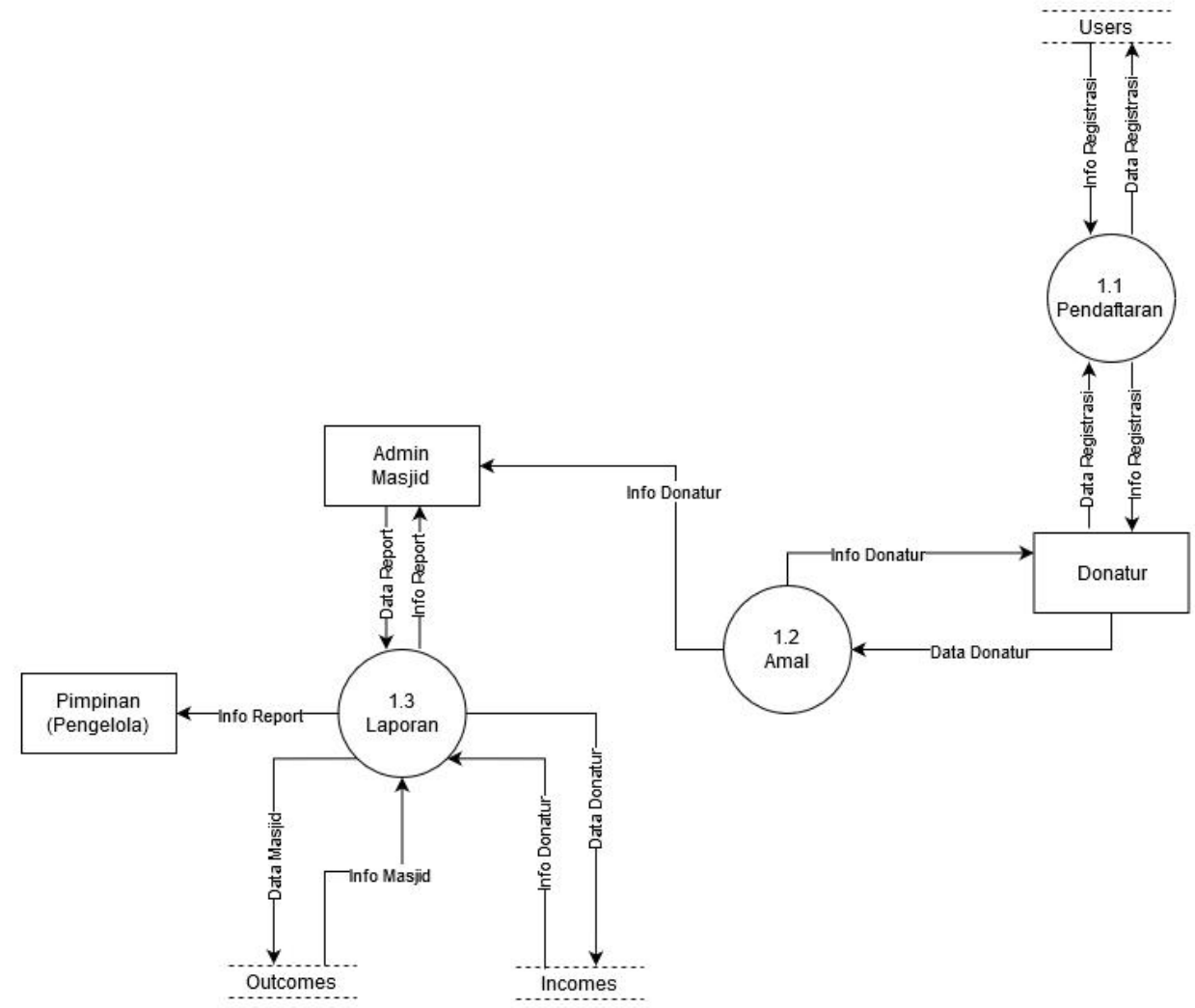

Figure 3 DFD Level 1 


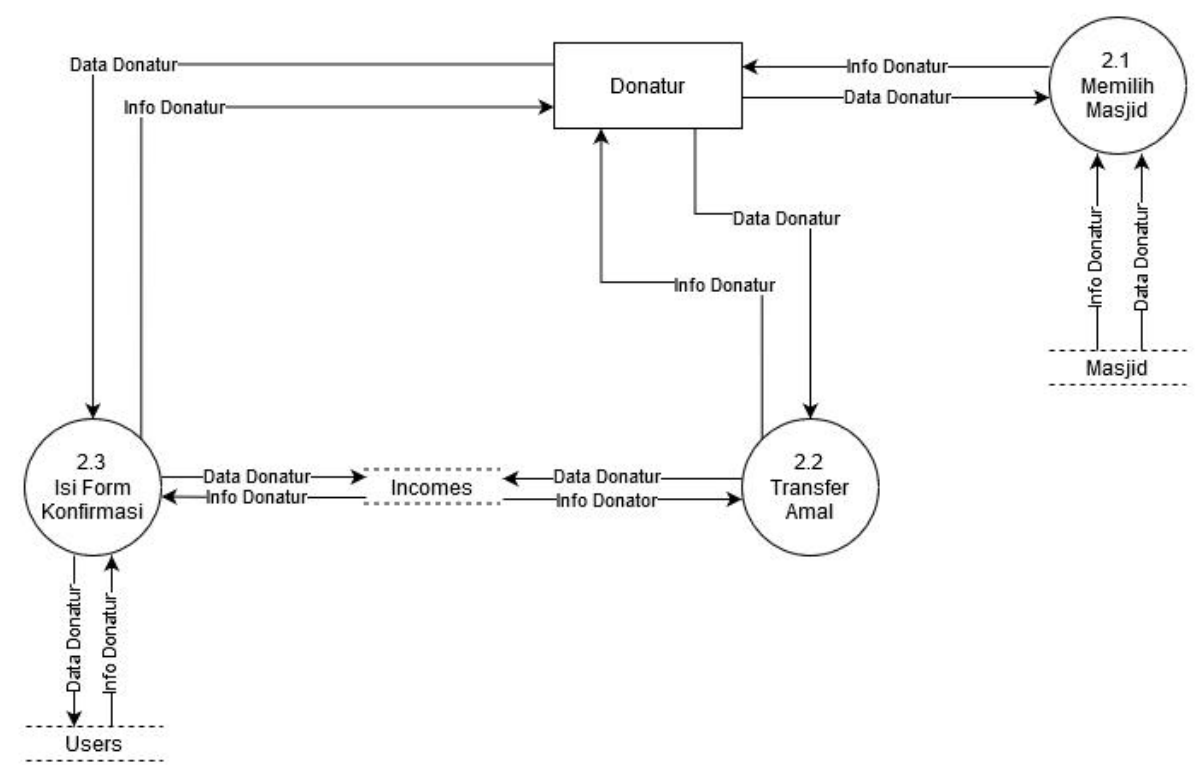

Figure 4 DFD Level 2

\subsection{Entity Relationship Diagram (ERD)}

Entity Relationship Diagram (ERD) adalah teknik yang digunakan untuk memodelkan kebutuhan data dari suatu organisasi, biasanya oleh pengalisis sistem dalam tahap analisis persyaratan proyek pengembangan sistem.
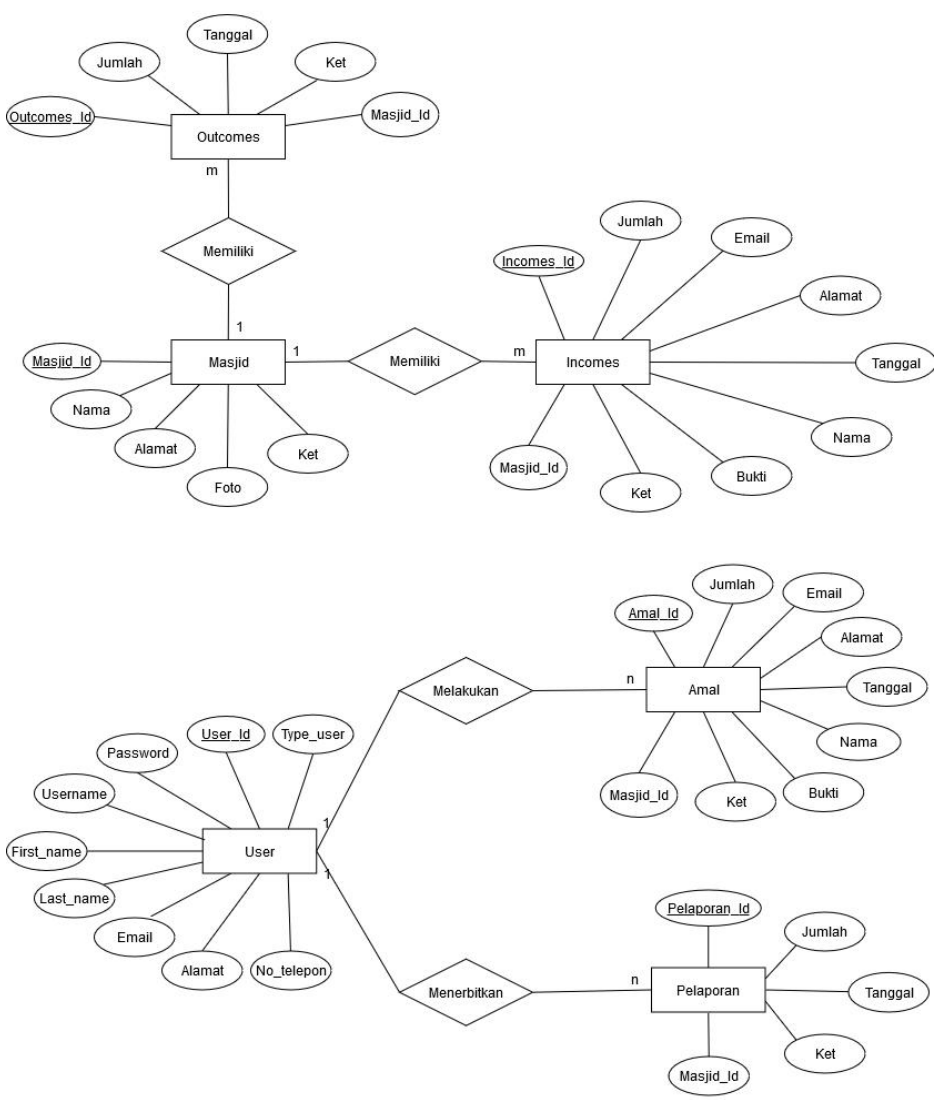

Figure 5 ERD 


\subsection{Database Design}

Pada database design, pengelola aplikasi lebih dulu menginputkan daftar masjid-masjid yang berada di suatu wilayah tertentu, contoh penelusuran kali ini ialah wilayah DKI Jakarta. Daftar masjid yang diinput tersebut nantinya terdapat hal-hal terkait id, nama masjid, foto, alamat, wilayah, uang amal saat ini, tanggal update, pengurus masjid, serta nomor rekening masjid atau pengurus masjid.

\subsection{Use Case Diagram}

Use case diagram adalah gambaran secara grafis dari beberapa atau semua actor, use case, dan interaksi, yang bertujuan untuk memperkenalkan suatu sistem. Berikut ini merupakan gambaran fungsi secara umum dengan Use Case Diagram dari perancangan sistem informasi yang dimaksud.

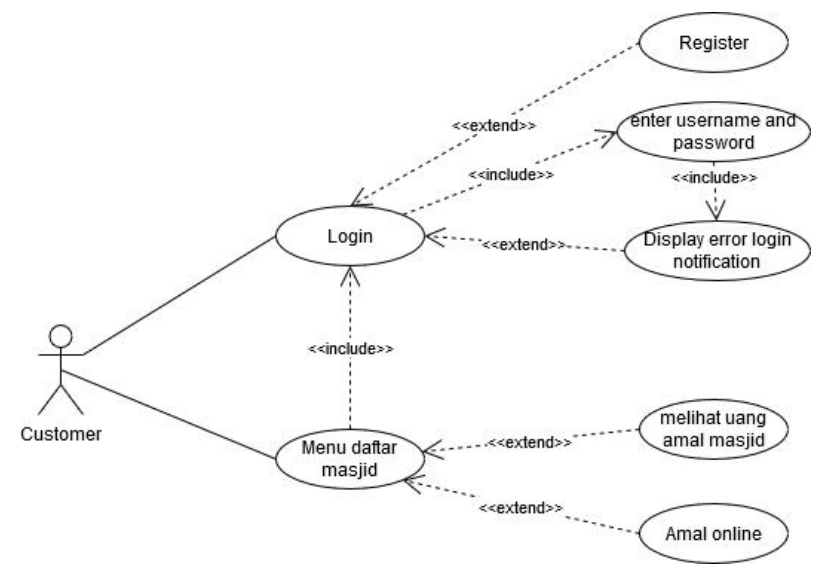

Figure 6 Use Case Diagram

\subsection{Activity Diagram}

Activity Diagram merupakan rancangan aliran aktivitas atau aliran kerja dalam sebuah sistem yang akan dijalankan. Activity Diagram ini dibuat berdasarkan sebuah atau beberapa use case. Berikut ini merupakan gambaran Activity Diagram untuk aktivitas login.

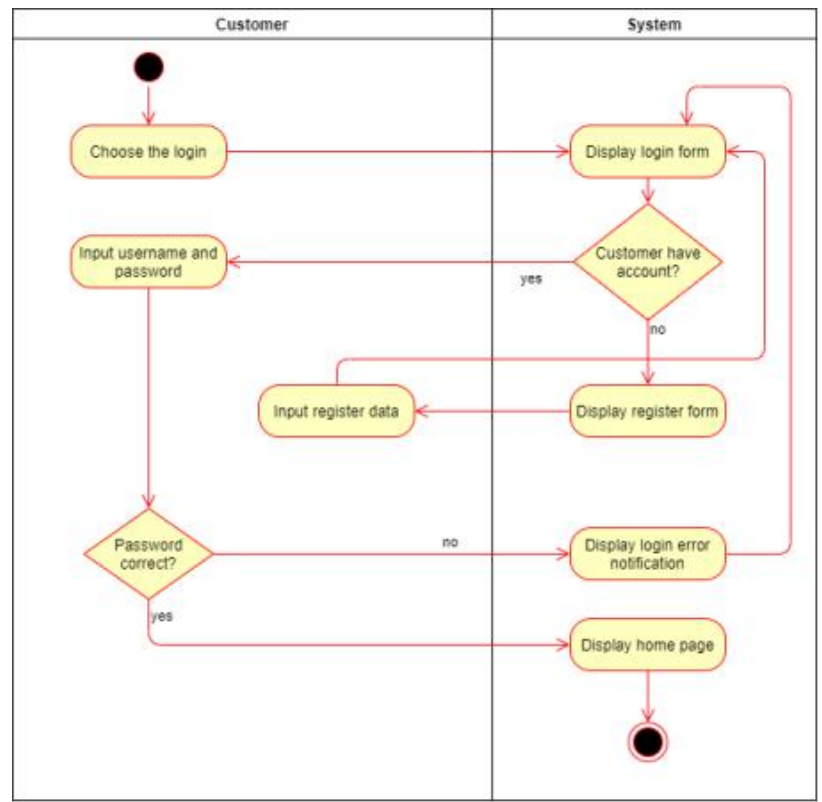

Figure 7 Activity Diagram 


\subsection{Sequence Diagram}

Sequence Diagram adalah diagram yang menggambarkan aliran pesan yang akan terjadi antar kelas dengan menggunakan operasi yang dimiliki kelas tersebut. Berikut ini merupakan Sequence Diagram dari untuk aktivitas login.

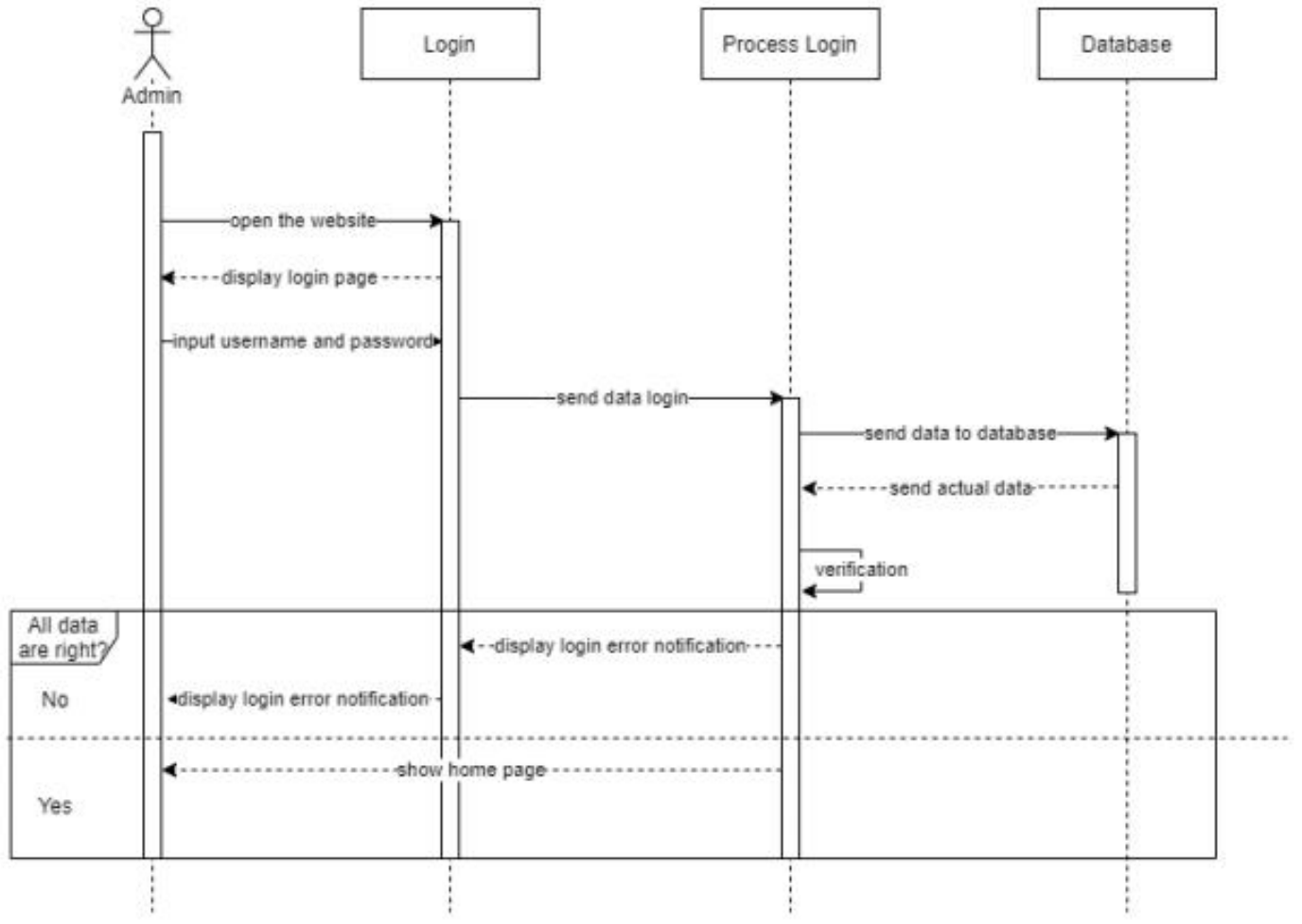

Figure 8 Sequence Diagram

3.8 Interface Design

Untuk Interface Design, terdapat tampilan form dan report yang akan tampil pada website. Tampilan form terdiri dari form data masjid yang terdapat pada Figure 9 dan report yang menampilkan hasil dari form data sebagaimana pada Figure 10.

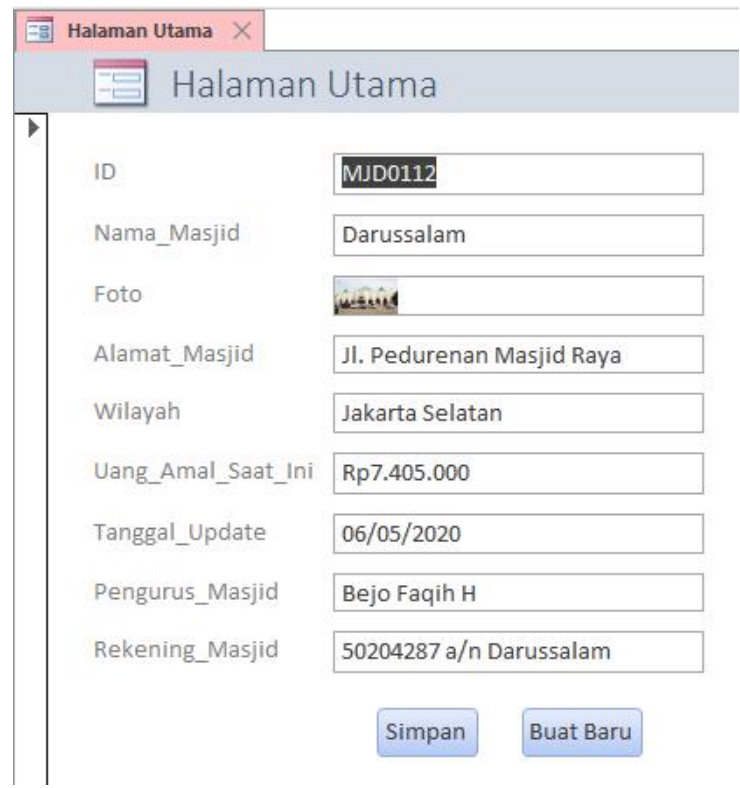

Figure 9 Tampilan Form 
Daftar Seluruh Masjid

\begin{tabular}{|c|c|c|c|c|c|c|c|c|c|}
\hline ID & Nama Masjid & Foto & Alamat Masjid & Wilayah & $\begin{array}{l}\text { Uang Amal } \\
\text { Saat ini }\end{array}$ & $\begin{array}{l}\text { Tanggal } \\
\text { Update }\end{array}$ & $\begin{array}{l}\text { Pengurus } \\
\text { Masjid }\end{array}$ & $\begin{array}{c}\text { Rekening } \\
\text { Masjid }\end{array}$ & \\
\hline MJD0112 & Darussalam & & $\begin{array}{l}\text { JI. Pedurenan } \\
\text { Masjid Raya }\end{array}$ & Jakarta Selatan & Rp7.405.000 & $06 / 05 / 2020$ & Bejo Faqih $\mathrm{H}$ & $\begin{array}{l}50204287 a / n \\
\text { Darussalam }\end{array}$ & Amal \\
\hline MJD0126 & Alhuda & & JI. Bangka No.10 & Jakarta Selatan & Rp5.259.000 & $10 / 05 / 2020$ & Siyam Amanah & $\begin{array}{l}52034274 \mathrm{a} / \mathrm{n} \\
\text { Amanah }\end{array}$ & Amal \\
\hline
\end{tabular}

Page 1 of 1

Figure 10 Tampilan Report

Selain itu, untuk melengkapi interface tersebut penulis juga membuat mockup seperti dibawah ini.

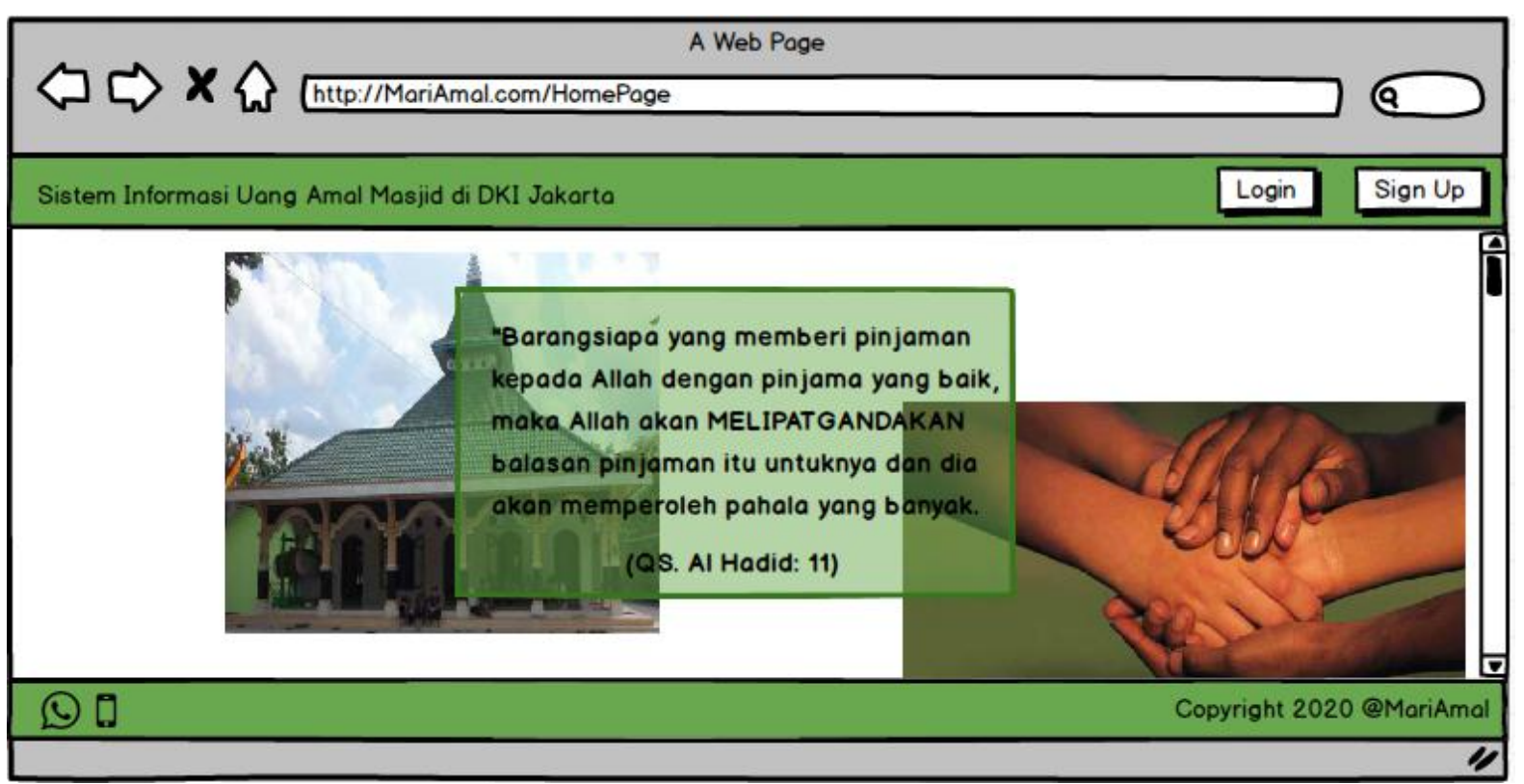

Figure 11 Tampilan Home Page

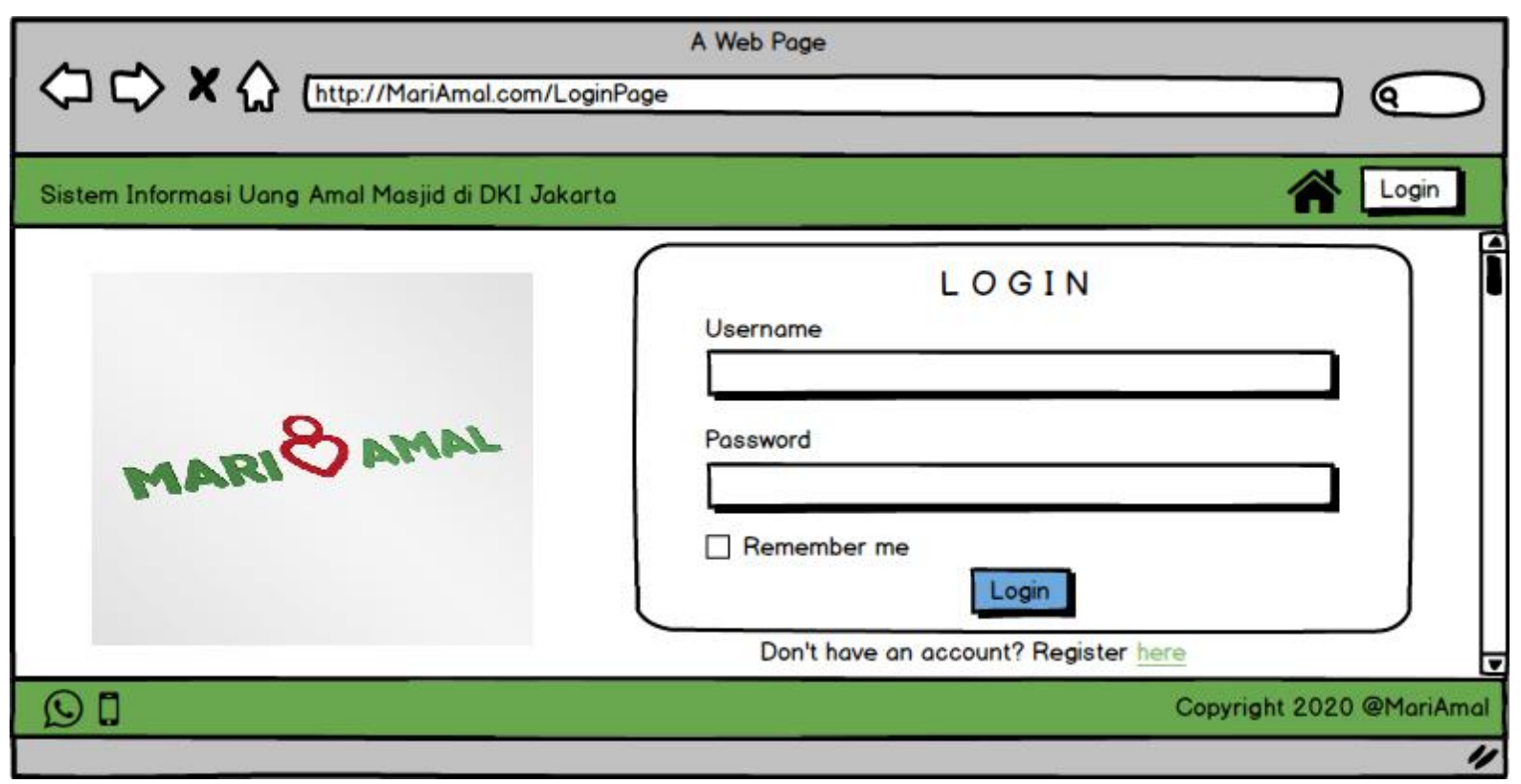

Figure 12 Tampilan Login 


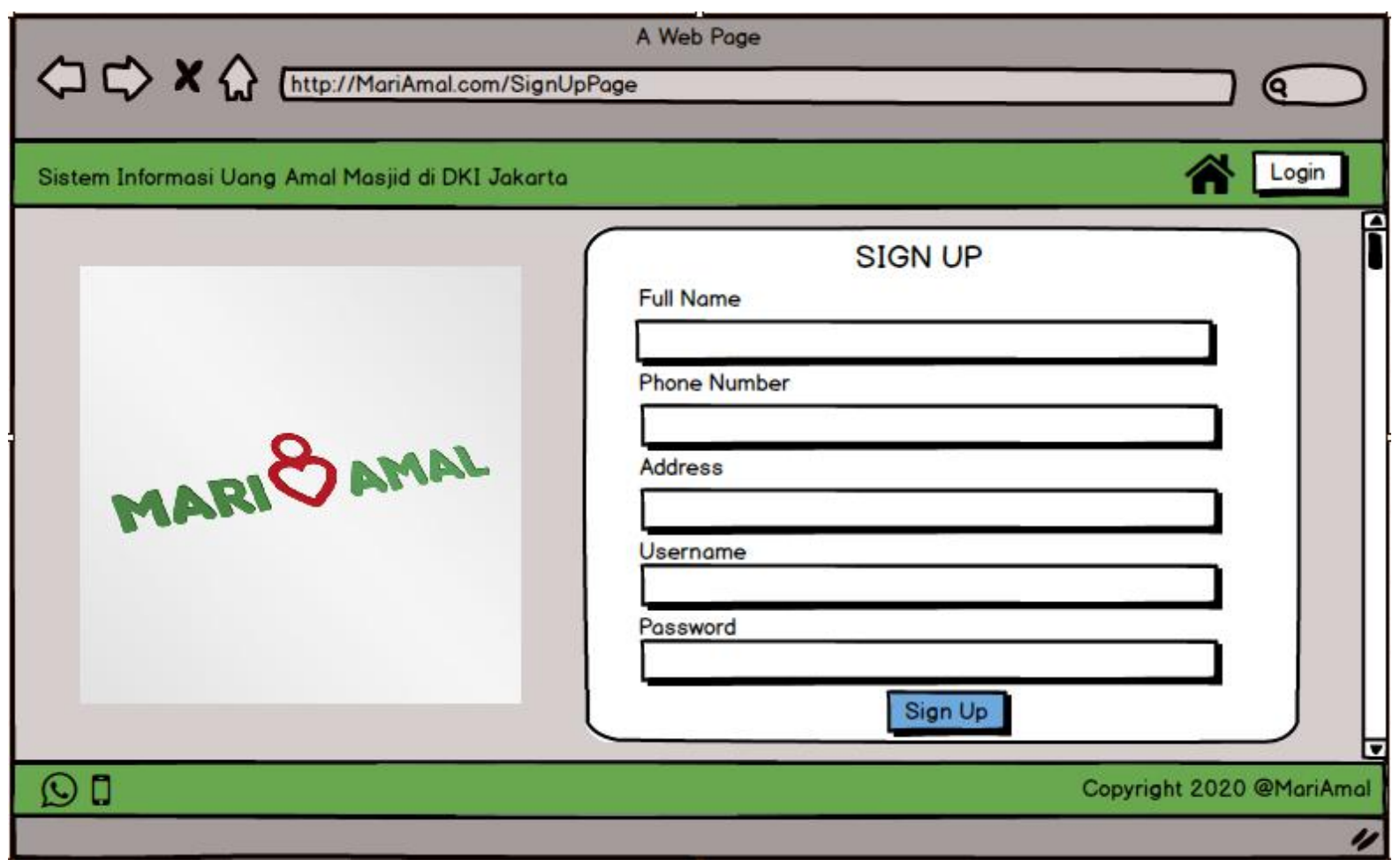

Figure 13 Tampilan Sign Up

\subsection{Source Code}

Singkatnya, source code merupakan kode program yang biasanya ditulis dalam satu atau lebih bahasa pemprograman yang dapat terbaca oleh manusia. Tujuan dari pemprograman ini sendiri adalah untuk menemukan urutan instruksi yang secara otomatis melakukan tugas tertentu atau memecahkan suatu masalah. Pada perancangan ini, dikarenakan menggunakan Ms. Access maka source code berupa query yang dapat dilihat pada gambar dibawah.

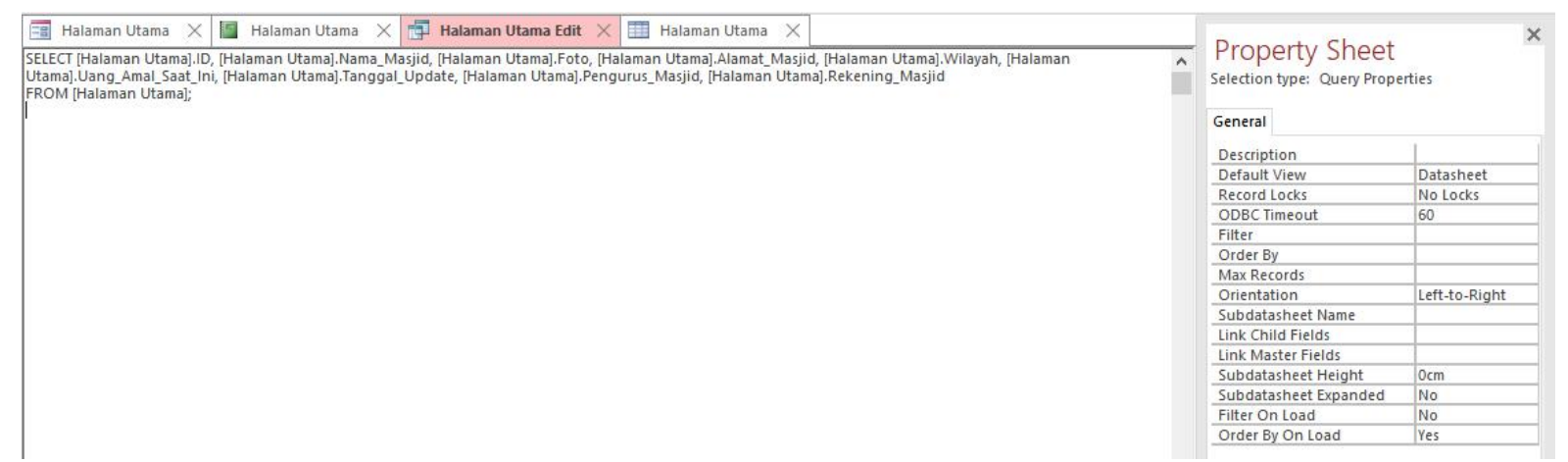

Figure 11 Query Ms Access

\section{Penutup}

\subsection{Kesimpulan}

Sistem Informasi ini berguna untuk hal-hal terkait transparansi uang amal masjid yang selalu up to date, yang penulis rasa hal tersebut belum ada dan dapat menjadi sarana yag baik bagi para donatur atau jama'ah yang ingin turut membantu kesetaraan dalam pembangunan masjid demi kenyamanan seluruh penggunanya. Selain itu, sistem informasi ini juga membantu untuk memperkenalkan masjid-masjid yang berada di suatu wilayah tertentu. Dalam Sistem Informasi ini juga terdapat nomor rekening resmi pengurus masjid yang telah di validasi terlebih dahulu oleh pengelola Aplikasi 
untuk donatur melakukan amal online. Tagline dari Aplikasi ini nantinya ialah "Beramal untuk Berlipat" dimana diharapkan tagline tersebut mampu menggerakkan hati para jama'ah untuk semakin ikhlas dalam berbagi.

\subsection{Saran}

Adapun saran dari penulis ialah masih banyak hal yang dapat dikembangkan lagi pada sistem informasi ini, baik dari segi UX maupun UI agar informasi dapat sampai dan diterima dengan baik oleh para penggunanya, serta fitur-fitur lainnya seperti pembayaran amal melalui gopay, ovo, dan semacamnya.

\section{References}

[1] C. May dkk, "Aplikasi Penggalangan Dana Komunitas Jumat Jaman Now Berbasis Web Menggunakan Framework Laravel,". Available: https://eprints.jeb.polinela.ac.id/417/1/Karya\%20Ilmiah\%20JJN.pdf

[2] D. Silvi, "Implementasi metode RAD pada Rancangan Aplikasi BAN-SOS Ter Distribusi Berbasis Mobile," Vol.3, $\quad$ No.1, Mei 2018.2 Available: https://ejournal.bsi.ac.id/ejurnal/index.php/ijcit/article/view/3761/2409

[3] N. Ayu, "Pengembangan Aplikasi berbasis Web Framework Laravel dengan Metodologi Rapid Application Development (RAD) untuk seekerja," Vol.1, No.1, 2020. Available: https://journal.uii.ac.id/AUTOMATA/article/view/13993

[4] Y. Socio dkk, "Pengembangan Sistem Informasi Penggalangan Donasi pada Yayasan Gerakan Nurani Orang Tua Asuh (GN-OTA) Kabupaten Lumajang," Vol.2, No.3, Mei 2018. Available: https://jptiik.ub.ac.id/index.php/j-ptiik/article/download/1397/490

Additional

[a] R. Aurachman, "Review Terhadap OSF.IO Sebagai Sarana Publikasi Preprint," OSF Preprints, 17 May 2020. doi:10.31219/osf.io/rvumx , Available: https://osf.io rvumx

[b] R. Aurachman, "Kerangka Perancangan Sistem Informasi Sebagai Pembelajaran Mahasiswa Teknik Industri," osf.io, doi:10.31219/osf.io/tmpen , 5 2020. Available: https://osf.io/tmpen 